\title{
POLYMYALGIA RHEUMATICA
}

\author{
Alastair G. Mowat and A. Virginia Camp, Oxford, England \\ From the Rheumatology Unit, Nuffield Department of Medicine and Orthopaedic Surgery, \\ University of Oxford, Nuffield Orthopaedic Centre, Oxford
}

Polymyalgia rheumatica is a clinical syndrome of unknown cause in which severe pain and stiffness of the muscles of the shoulder and pelvic girdles are accompanied by a variety of systemic symptoms and signs.

The syndrome has been increasingly recognised over the past decade, although the first description appeared before the turn of the century (Bruce 1888). The syndrome has been described since under a variety of different names (Hunder, Disney and Ward 1969), but that of polymyalgia rheumatica is now used in reports in English. The syndrome is important because it is common; it causes much distress by the severity of the musculo-skeletal symptoms; the diagnosis is often missed and the symptoms are ascribed to degenerative joint disease or to psychological illness. Serious systemic involvement with arteritis may be present. The syndrome is amenable to treatment.

Most reports of the syndrome have come from rheumatologists or general physicians and its presentation as an orthopaedic condition has been largely ignored. However, the prominent musculo-skeletal symptoms would suggest that some of these patients would be referred to orthopaedic surgeons, and this has been confirmed by our experience. A survey of the cases seen in the rheumatology department of this hospital showed that almost half the patients were seen initially by orthopaedic surgeons.

\section{CLINICAL MATERIAL}

Twenty-three patients with polymyalgia rheumatica have been seen in a rheumatology unit in the past two years. During this period 525 patients were referred to the unit, so the incidence is 4.5 per cent. Eleven of the patients had been seen initially by orthopaedic surgeons, three had been referred from other medical units and nine directly from the general practitioner. Three of the eleven patients seen by orthopaedic surgeons were referred for continuing care when the unit opened, and examination of the hospital records showed that these were the only cases diagnosed as polymyalgia rheumatica during the previous five years. This suggests that a number of cases had been missed.

Details of the patients' symptoms and signs, which are set out in Table I, were compiled from the case records and from personal interviews. All patients were seen by us on several occasions including the final follow-up examination. Estimations of the haemoglobin, erythrocyte sedimentation rate (Westergren) and the latex titre for rheumatoid factor were made on initial and final examinations. The results are shown in Table II. Details of treatment and its duration, and the length of the follow-up period are set out in Table III. The mean length of follow-up from the onset of the syndrome was twenty-two and a half months and from diagnosis sixteen and a half months. The delay between the onset of symptoms and diagnosis ranged from one to twenty months. When patients were referred to an orthopaedic surgeon the mean delay was six and a half months compared with four and a half months for the others.

\section{INCIDENCE}

Polymyalgia rheumatica was found to account for 1.3 per cent of all cases in a rheumatic diseases clinic by Dixon, Beardwell, Kay, Wanka and Wong (1966). The incidence was the same as that of gout, greater than that of ankylosing spondylitis, and in patients over seventy 
TABLE I

Symptoms and Signs in Polymyalgia Rheumatica

\begin{tabular}{|c|c|c|c|c|c|c|c|}
\hline $\begin{array}{c}\text { Case } \\
\text { number }\end{array}$ & Sex & $\begin{array}{c}\text { Age } \\
\text { (years) }\end{array}$ & $\begin{array}{c}\text { Source } \\
\text { Orthopaedic: } \mathbf{O} \\
\text { Medical: M } \\
\text { Practitioner: P }\end{array}$ & $\begin{array}{l}\text { Prodromal } \\
\text { symptoms }\end{array}$ & $\begin{array}{l}\text { Sudden onset: } \mathbf{S} \\
\text { Gradual: } \mathbf{G}\end{array}$ & $\begin{array}{c}\text { Involvement } \\
\text { Shoulder girdle: } \mathbf{S} \\
\text { Pelvic girdle: } \mathbf{P}\end{array}$ & $\begin{array}{c}\text { Amount of } \\
\text { pain }\end{array}$ \\
\hline 1 & Female & 43 & $\mathrm{O}$ & Trauma & G & S P & $t+t$ \\
\hline 2 & Male & 52 & $\mathrm{O}$ & & G & S P & +++ \\
\hline 3 & Male & 56 & $\mathrm{O}$ & & Very $\mathbf{S}$ & S P & +++ \\
\hline 4 & Male & 58 & $M$ & & G & S P & +++ \\
\hline 5 & Female & 58 & $\mathbf{P}$ & & $\mathbf{S}$ & S P & ++ \\
\hline 6 & Female & 59 & $\mathbf{P}$ & Influenza & $\mathbf{S}$ & S P & $+t$ \\
\hline 7 & Female & 60 & $\mathrm{O}$ & & $G$ & S P & ++ \\
\hline 8 & Female & 63 & $\mathbf{P}$ & & G & S. Thighs & +++ \\
\hline 9 & Female & 63 & $\mathrm{O}$ & & G & S P & ++ \\
\hline 10 & Male & 64 & $\mathrm{O}$ & Trauma & G & S P & + \\
\hline 11 & Male & 64 & $\mathrm{O}$ & & G & S P & $+t+$ \\
\hline 12 & Male & 65 & $\mathrm{O}$ & Trauma & $\mathbf{S}$ & S P & $+t$ \\
\hline 13 & Female & 65 & $P$ & & $S$ & S P & $+t$ \\
\hline 14 & Male & 66 & $\mathbf{P}$ & & Very $\mathbf{S}$ & $\begin{array}{c}\text { S P. } \\
\text { All limb muscles }\end{array}$ & +++ \\
\hline 15 & Female & 66 & $\mathrm{O}$ & & G & S P & ++ \\
\hline 16 & Female & 68 & $P$ & & $\mathrm{~S}$ & S P & ++ \\
\hline 17 & Female & 69 & $\mathrm{O}$ & & G & S P & $t+$ \\
\hline 18 & Female & 75 & $\mathbf{P}$ & & S & S P & +++ \\
\hline 19 & Female & 75 & $\mathrm{O}$ & & $\mathbf{S}$ & $\begin{array}{l}\text { S P. Proximal } \\
\text { limb muscles }\end{array}$ & +++ \\
\hline 20 & Female & 76 & $P$ & & $\mathbf{S}$ & S P & ++ \\
\hline 21 & Female & 76 & $\mathbf{P}$ & & $\mathrm{S}$ & S P & +++ \\
\hline 22 & Male & 77 & $\mathbf{M}$ & & G & S P. Forearms & +++ \\
\hline 23 & Female & 77 & $\mathbf{M}$ & & G & S P & ++ \\
\hline
\end{tabular}

years of age, one-half that of rheumatoid arthritis. The older patients involved and the seriousness of the syndrome are emphasised by the findings that the incidence falls to one-tenth of that for rheumatoid arthritis when the whole hospital population is considered (Andrews 1966) and accounted for 7 per cent of the admissions to a Swedish rheumatic diseases hospital (Kogstad 1965). Similar results have been reported from North America (Wilske and Healey 1967). The higher incidence of 4.5 per cent found in the present series probably reflects the small number of patients with degenerative joint diseases referred to this unit.

Age and sex-Polymyalgia rheumatica usually affects those over sixty years of age. The commonest age group involved is that between sixty-five and seventy years and the mean age 
TABLE I-continued

Symptoms and Signs in Polymyalgia Rheumatica

\begin{tabular}{|c|c|c|c|c|c|c|c|}
\hline $\begin{array}{l}\text { Amount of } \\
\text { muscle } \\
\text { tenderness }\end{array}$ & $\begin{array}{l}\text { Hours of } \\
\text { morning } \\
\text { stiffness }\end{array}$ & $\begin{array}{l}\text { Night } \\
\text { sweats }\end{array}$ & Malaise & Depression & $\begin{array}{c}\text { Weight } \\
\text { loss } \\
\text { (kilograms) }\end{array}$ & $\begin{array}{l}\text { Vascular symptoms } \\
\text { and signs }\end{array}$ & $\begin{array}{c}\text { Joint } \\
\text { involvement }\end{array}$ \\
\hline- & 4 & + & + & + & $3 \cdot 6$ & & \\
\hline$i$ & 4 & & + & $\div$ & $6 \cdot 4$ & & Sterno-clavicular \\
\hline \multirow[t]{2}{*}{$\dot{r}$} & 6 & 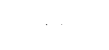 & - & $\div$ & - & & \\
\hline & 6 & & + & + & $3 \cdot 2$ & & Knees \\
\hline+ & 5 & + & - & + & - & Angina & \\
\hline$\div-\quad \cdot$ & 3 & $\therefore$ & + & + & - & & \\
\hline$\uparrow$ & 6 & + & + & + & $6 \cdot 4$ & & Hands \\
\hline+ & 6 & + & + & $\div$ & $3 \cdot 2$ & & \\
\hline$\because$ & 6 & & $\div$ & + & - & & \\
\hline$\therefore$ & 3 & 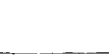 & - & - & - & & \\
\hline$\therefore$ & 6 & $\cdots$ & - & + & $3 \cdot 2$ & Femorals: Bruits & \\
\hline- & 6 & 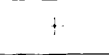 & + & + & $6 \cdot 4$ & & Hands and knces \\
\hline$\therefore$ & 3 & 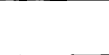 & - & $\div$ & - & & \\
\hline$\therefore:$ & 6 & $\dot{t}$ & + & + & $9 \cdot 6$ & & \\
\hline+1 & 4 & - & + & + & $12 \cdot 7$ & Angina & Knees \\
\hline$\therefore$ & 6 & t. & + & + & $3 \cdot 2$ & & Sterno-c'avicular \\
\hline- & 6 & - & $\div$ & $\div$ & $22 \cdot 2$ & $\begin{array}{c}\text { Angina. } \\
\text { Tender temporals }\end{array}$ & \\
\hline++ & 4 & + & + & + & $3 \cdot 2$ & $\begin{array}{c}\text { Tender femorals. } \\
\text { Bruits }\end{array}$ & Knecs \\
\hline+4 & 4 & - & + & + & $6 \cdot 4$ & Subclavian bruit & \\
\hline$\cdots$ & 4 & & + & + & - & Angina and infarct & \\
\hline+ & 2 & - & - & - & - & & \\
\hline+ & 6 & - & - & - & - & & Hands \\
\hline$\because+-$ & 4 & & - & + & $3 \cdot 2$ & & \\
\hline
\end{tabular}

of the patients in most series falls within this group (Gunderson 1970). The mean age of our twenty-three patients at the onset of the disease was $64 \cdot 8$ years. However, younger patients are not exempt: the youngest patient recorded was nineteen years of age (Hunder et al. 1969) and 4 per cent of patients are under fifty. In this series there was one patient aged forty-three years and there were five others under the age of sixty. The syndrome is usually more severe and the incidence of arteritis higher in those over sixty years (Bruk 1967).

The syndrome is commoner in women. Fifteen of our twenty-three cases were in women, which is very close to the 63 per cent of 525 cases reported in the literature (Weissenbach, Nobillot, Freneaux and Coste 1963).

VOL. 53 B, NO. 4, NOVEMBER 1971 
TABLE II

Laboratory Findings in Polymyalgia Rheumatica

\begin{tabular}{|c|c|c|c|c|c|c|c|c|}
\hline \multirow[b]{2}{*}{$\begin{array}{c}\text { Case } \\
\text { number }\end{array}$} & \multicolumn{5}{|c|}{ Initial } & \multirow{2}{*}{\multicolumn{2}{|c|}{ 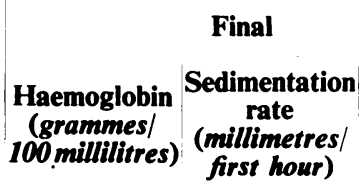 }} & \multirow[b]{2}{*}{$\begin{array}{c}\text { Latex } \\
\text { test }\end{array}$} \\
\hline & $\begin{array}{c}\text { Haemoglobin } \\
\text { (grammes/ } \\
100 \text { millilitres) }\end{array}$ & $\begin{array}{c}\text { Sedimentation } \\
\text { rate } \\
\text { (millimetres/ } \\
\text { first hour) }\end{array}$ & $\begin{array}{l}\text { White cell } \\
\text { count (cubic } \\
\text { millimetre) }\end{array}$ & $\underset{\text { test }}{\text { Latex }}$ & $\begin{array}{c}\text { Temporal } \\
\text { artery } \\
\text { biopsy }\end{array}$ & & & \\
\hline 1 & $12 \cdot 3$ & 67 & - & Negative & - & $14 \cdot 3$ & 14 & Negative \\
\hline 2 & $12 \cdot 0$ & 43 & 5,400 & Negative & - & 14.9 & 8 & Negative \\
\hline 3 & $13 \cdot 8$ & 46 & 7,400 & Negative & - & $15 \cdot 6$ & 11 & Negative \\
\hline 4 & $10 \cdot 2$ & 104 & 9,400 & Negative & Normal & 13.0 & 20 & Negative \\
\hline 5 & $13 \cdot 2$ & 30 & 9,500 & Negative & - & $11 \cdot 3$ & 19 & Negative \\
\hline 6 & $12 \cdot 1$ & 24 & 9,500 & Negative & - & 13.9 & 5 & Negative \\
\hline 7 & $13 \cdot 8$ & 95 & - & Negative & Normal & $14 \cdot 6$ & 19 & Negative \\
\hline 8 & $13 \cdot 2$ & 24 & 9,500 & Negative & - & $13 \cdot 8$ & 9 & Negative \\
\hline 9 & $9 \cdot 3$ & 53 & 4,500 & Negative & - & $12 \cdot 6$ & 11 & Negative \\
\hline 10 & $13 \cdot 2$ & 91 & 8,900 & Negative & - & $14 \cdot 7$ & 5 & Negative \\
\hline 11 & $11 \cdot 4$ & 61 & 12,100 & Negative & - & $12 \cdot 8$ & 11 & Negative \\
\hline 12 & $12 \cdot 6$ & 40 & 9,800 & Negative & Normal & $14 \cdot 6$ & 3 & Negative \\
\hline 13 & $11 \cdot 2$ & 68 & 6,800 & Negative & - & $10 \cdot 4$ & 25 & Negative \\
\hline 14 & $12 \cdot 9$ & 46 & 11,900 & Negative & - & $14 \cdot 2$ & 5 & Negative \\
\hline 15 & $13 \cdot 7$ & 55 & 8,000 & Negative & Normal & $11 \cdot 8$ & 44 & Negative \\
\hline 16 & $13 \cdot 3$ & 33 & 9,600 & Negative & - & $12 \cdot 9$ & 63 & Negative \\
\hline 17 & 8.0 & 115 & 7,400 & Negative & Arteritis & $14 \cdot 2$ & 17 & Negative \\
\hline 18 & $8 \cdot 2$ & 107 & 9,700 & Negative & Arteritis & 13.9 & 4 & Negative \\
\hline 19 & $12 \cdot 7$ & 50 & 6,300 & weak + & Normal & $15 \cdot 2$ & 3 & Negative \\
\hline 20 & $11 \cdot 7$ & 84 & 7,300 & Negative & - & 13.9 & 20 & Negative \\
\hline 21 & $13 \cdot 5$ & 118 & - & Negative & - & - & - & Negative \\
\hline 22 & $12 \cdot 0$ & 65 & 10,000 & weak + & - & $15 \cdot 1$ & 22 & weak + \\
\hline 23 & $12 \cdot 3$ & 78 & - & Negative & Normal & $13 \cdot 3$ & 42 & Negative \\
\hline
\end{tabular}

\section{CLINICAL FEATURES}

The symptoms and signs are shown in Table I. In a few cases there may be a prodromal illness resembling influenza, as was noted in one of our cases, and in others a bacterial infection, such as tonsillitis, appears to be the initial event. However, these infections are probably incidental because viral studies have produced negative results (Plotz and Spiera 1969) and bacterial causes, particularly chronic brucellosis, have been excluded (Wilske and Healey 1967). Recent trauma, reported by three of our patients as the initial event, is also probably coincidental.

The onset of the syndrome is often dramatic and the patients may give the date and hour of their first symptoms. In most cases the syndrome becomes fully developed within a month (Gordon 1960). Eleven of our patients had the fully developed syndrome within three or 
TABLE III

Treatment and Results of Polymyalgia Rheumatica

\begin{tabular}{|c|c|c|c|c|c|c|c|}
\hline \multirow{3}{*}{$\begin{array}{c}\text { Case } \\
\text { number }\end{array}$} & \multicolumn{4}{|c|}{ Treatment } & \multicolumn{3}{|c|}{ Time in months } \\
\hline & \multicolumn{2}{|c|}{$\begin{array}{l}\text { Prednisolone } \\
\text { (milligrams per day) }\end{array}$} & \multirow{2}{*}{ Other } & \multirow[t]{2}{*}{ Result } & \multirow{2}{*}{ Diagnosis } & \multirow{2}{*}{ Cure } & \multirow{2}{*}{ Follow-up } \\
\hline & Initial & Final & & & & & \\
\hline 1 & 10 & 0 & - & Cured & 4 & 10 & 18 \\
\hline 2 & 20 & 0 & - & Cured & 8 & 15 & 23 \\
\hline 3 & - & - & Indomethacin & Cured & 20 & 24 & 41 \\
\hline 4 & 20 & 10 & - & Improved & 2 & - & 5 \\
\hline 5 & 15 & 6 & - & Improved & 6 & - & 13 \\
\hline 6 & - & - & Indomethacin & Cured & 7 & 10 & 20 \\
\hline 7 & 10 & 4 & -- & Improved & 3 & - & 12 \\
\hline 8 & 7.5 & $2 \cdot 5$ & - & Improved & 3 & - & 13 \\
\hline 9 & 10 & 5 & - & Improved & 3 & - & 10 \\
\hline 10 & - & 一 & $\begin{array}{l}\text { Soluble aspirin. } \\
\text { Indomethacin }\end{array}$ & Cured & 3 & 6 & 13 \\
\hline 11 & 15 & 0 & - & Cured & 3 & 9 & 48 \\
\hline 12 & 20 & $7 \cdot 5$ & - & Improved & 7 & - & 10 \\
\hline 13 & 5 & 0 & - & Cured & 3 & 12 & 17 \\
\hline 14 & - & - & Soluble aspirin & Cured & 2 & 8 & 12 \\
\hline 15 & 10 & 2 & - & Improved & 7 & - & 51 \\
\hline 16 & 10 & 0 & - & Cured & 12 & 18 & 28 \\
\hline 17 & 30 & 2 & - & Improved & 10 & - & 57 \\
\hline 18 & 40 & $12 \cdot 5$ & - & Improved & 5 & - & 10 \\
\hline 19 & 20 & $7 \cdot 5$ & - & Improved & 3 & - & 7 \\
\hline 20 & 15 & 0 & - & Cured & 1 & 18 & 21 \\
\hline 21 & 10 & - & - & Improved & 3 & - & 4 \\
\hline 22 & - & - & Indomethacin & Cured & 7 & 12 & 21 \\
\hline 23 & 20 & 0 & - & Cured & 6 & 36 & 60 \\
\hline
\end{tabular}

four days of the onset, and two of these patients could give the exact date and hour of the onset of the symptoms, which were severe from the outset.

The patients complain of pain and stiffness in the shoulder and pelvic girdles, with occasional involvement of the proximal limb muscles. The symptoms are almost always bilateral and sometimes symmetrical. Two patients described symmetrical involvement and four had involvement of the limb muscles. Similar symptoms may be noted in periarticular structures including bursae, tendons and joint capsules. The symptoms are most severe in the morning and may persist for four to six hours. Many patients are so severely affected in the early stages of the disease that they become totally dependent upon others. Only a few are still able to work or undertake normal household duties. There is usually tenderness of the involved structures, but the muscle tenderness is not so severe as that found with myositis.

VOL. 53 B, NO. 4, NOVEMBER 1971 
Active joint movement, particularly at the hips and shoulders, is restricted by pain and softtissue involvement. Passive joint movement is almost full, although capsulitis of the shoulders is likely to develop if treatment is not given promptly. Disuse of joints may result in muscle wasting. Transient swelling and synovitis may occur in any joint (Hunder et al. 1969). Symptomless knee effusions were noted in eight of eighteen patients by Wilske and Healey (1967). Bruk (1967) found synovial thickening or effusion in two-thirds of his eighty cases, the knee (forty) and the sterno-clavicular joint (thirty-two) being the most commonly involved. In some cases it is difficult to exclude osteoarthrosis as the cause of the joint symptoms. In our series there were bilateral effusions of the knees in four patients, mild synovial thickening in the small joints of the hands in three patients and synovial proliferation of one sternoclavicular joint in two patients.

The patients look unwell and complain of fatigue, lassitude and depression. Anorexia and loss of weight may be striking and suggest neoplasia. A loss of between 3 and 21 kilograms was noted by fourteen of our patients. Many patients have night sweats and fever, although the temperature seldom exceeds 37.8 degrees Centigrade as in our Cases 17, 18 and 19 and as noted by others (Hamrin, Jonsson and Landberg 1965; Andrews 1966). Symptoms attributable to vascular involvement are often mentioned by the patients and these are discussed in greater detail later.

\section{LABORATORY FINDINGS}

The main laboratory findings are summarised in Table II. Mild hypochromic anaemia is frequent but resolves without specific treatment as the disease is controlled. The mean haemoglobin value in our twenty-three patients was 12 grammes per 100 millilitres on diagnosis and 13.7 grammes per 100 millilitres on final examination.

One of the most striking features of polymyalgia rheumatica is the high erythrocyte sedimentation rate, values of over 100 millimetres in the first hour (Westergren) being recorded in this and other series (Hunder et al. 1969). The rate returns to normal as the disease subsides. The mean sedimentation rate in this series was 64 millimetres in the first hour on diagnosis and 17 millimetres in the first hour on final examination. Resolution of symptoms precedes the fall in the sedimentation rate, which is therefore not a good guide to management. It has been suggested that those with the highest sedimentation rates are more likely to have underlying arteritis (Bruk 1967). The selective nature of our arterial biopsies hardly allows of such a comparison, but it is of interest that two of three patients with a sedimentation rate over 100 millimetres in the first hour had histological changes of temporal arteritis.

The white cell count is usually normal, although a slight leucocytosis, sometimes with a modest eosinophilia, has been recorded (Bagratuni 1963, Weissenbach et al. 1963). Two of our patients had a white cell count greater than 10,000 per cubic millimetre but the differential count was normal in all patients.

The tests for rheumatoid factor in the serum are usually negative (Gordon 1960). In this series weak positive results were found at the start in two patients, in one of whom it remained weakly positive. This incidence is much the same as that recorded by Hunder et al. (1969) in which nineteen of 250 patients ( 7.6 per cent) had positive tests. This incidence is not greater than that expected in a population of this age (Ball and Lawrence 1961).

Protein electrophoresis shows a non-specific rise in alpha 2 globulin with less frequent elevations of alpha 1 and gamma globulins. Plasma fibrinogen values may be greatly elevated (Goodman and Pearson 1969). The tests for anti-nuclear factor and lupus erythematosus cells are negative and the serum values of alkaline phosphatase, calcium and phosphorus are normal (Goodman and Pearson 1969). The serum enzymes, glutamic-oxaloacetic transaminase, aldolase and creatine phosphokinase, which are elevated with myositis, are normal. All these observations were confirmed in the present series. Electromyography is normal (Chalmers, Alexander and Duthie 1964; Bruk 1967). Muscle biopsy is also normal, although in a few 
cases a larger vessel involved in the arteritic process may be present to provide diagnostic help.

The synovial fluid usually has the characteristics of an inflammatory exudate (Wilske and Healey 1967). Synovial tissue biopsy shows non-specific inflammatory changes (Gordon 1960, Bruk 1967).

Radiographs often show degenerative changes consistent with the patient's age. Osteoporosis is a common finding. Changes in the sacro-iliac joints with sclerosis, narrowing of the joint space and minor erosive changes were noted by Bruk (1967) in seventeen of eighty patients and Andrews (1966) noted similar changes in eleven of twenty-seven patients but in only two of twenty-seven matched controls. Similar radiographic changes may occur in other joints, the sterno-clavicular joints and the symphysis pubis being the most commonly involved (Bruk 1967). Characteristic radiographic changes were found in the sacro-iliac joints of one of our patients (Case 3).

\section{VASCULAR INVOLVEMENT}

In many cases of polymyalgia rheumatica an underlying vasculitis can be shown and this may be responsible for most or all of the manifestations of the syndrome, either by direct involvement of structures or by causing referred pain and stiffness. Hunder et al. (1969) examined the findings in 356 patients, of whom 167 had temporal artery biopsy. The pathology of arteritis was found in eighty-four (50 per cent). However, because in sixty patients there were strong clinical indications that the biopsy would be positive, the authors suggested that a more realistic incidence of temporal arteritis would be twenty-four of 107 cases ( 22 per cent).

The temporal artery is usually selected for biopsy because it is easily accessible and because its involvement often causes pain in the face, headache, local tenderness and nodularity. However, the widespread nature of the vasculitis has been well documented. Involvement of the aorta and related large vessels with the development of the aortic arch syndrome (Hamrin, Jonsson and Hellsten 1968), of major leg vessels with symptoms of claudication (Hunder and Sheps 1967), of the uterine vessels (Polasky, Polasky, Magenheim and Abrams 1965), and of the heart with granulomatous myocarditis (Hamrin et al. 1968) have all been confirmed in pathological specimens. Many other symptoms have been attributed to this underlying vasculitis. The most serious of these are visual disturbances from involvement of the ophthalmic or central retinal arteries which may lead to transient or permanent blindness or central field defects and which can be a severe handicap in the elderly (Bruk 1967, Fessel and Pearson 1967, Hamrin et al. 1968, Simkin and Healey 1969). In our series one patient suffered a variety of transient visual disturbances (Case 18) and a second lost all but peripheral vision in the left eye (Case 23). Diplopia due to the involvement of the extra-ocular muscles also occurs (Lockshin 1970). Other symptoms include pain in the face on chewing, angina and gangrene of the tongue (Henderson 1967), scalp gangrene (Grahame, Bluestone and Holt 1968), abdominal pain due to mesenteric vessel involvement (Simkin and Healey 1969), dysphagia (Desser 1969), hallucinations (Hart 1967) and psychosis (Paulley and Hughes 1960). It is often difficult to attribute vascular symptoms to an underlying arteritis without pathological evidence when the population at risk can expect to have vascular symptoms from atherosclerosis. Thus, four of our patients suffered angina pectoris of recent onset, of whom three appeared to improve on treatment for the polymyalgia rheumatica.

The arteritis is histologically a pan-arteritis with giant-cell granuloma formation, fragmentation of elastic fibres, intimal thickening and thrombus formation; the involvement is patchy and "skip lesions" are commonly found (Goodman and Pearson 1969). The patchy involvement has been repeatedly emphasised by the normal histology of temporal artery biopsies in patients with obvious clinical signs (Bevan, Dunnill and Harrison 1968) and, more important, the finding of pathological changes in biopsies from patients without symptoms (Alestig and Barr 1963; Kogstad 1965; Nuessle, Miller and Norman 1967; Cullen 1967).

VOL. $53 \mathrm{~B}$, NO. 4, NOVEMBER 1971 
Because temporal artery biopsy is unreliable only eight biopsies were done in this series. The two biopsies that showed arteritis were in patients with the suggestive symptoms and signs of headache, transient visual disturbance, and tender nodular vessels and absent pulsation. The patient who lost the sight of one eye had a biopsy late in the disease and it was normal.

Other investigations may be helpful. Gillanders, Strachan and Blair (1969) recommended a temporal artery angiogram which may assist in the selection of the biopsy site. Palpation and ausculation of the large vessels have been recommended because there may be vascular tenderness and a bruit. Bruk (1967) found bruits in twenty-two of his eighty patients, often in several sites, but particularly over the subclavian vessels. Similar but usually softer bruits from atherosclerosis were found in only six of eighty controls. Hamrin et al. (1965) found a similar distribution of bruits in 58 per cent of fifty-two patients but in only 12 per cent of a matched control group. In our series bilateral femoral bruits were heard in two patients with associated vascular tenderness in one of them, and a left subclavian bruit in a third.

\section{DIFFERENTIAL DIAGNOSIS}

The presenting symptoms, signs and investigations listed above should enable a correct diagnosis to be made, provided polymyalgia rheumatica is considered. Delay in diagnosis, which in our series averaged six months, causes the patient unnecessary suffering and may result in vascular lesions. Polymyalgia rheumatica is probably the same disease as temporal (cranial or giant-cell) arteritis (Simkin and Healey 1969, Plotz and Spiera 1969). Musculoskeletal symptoms are generally more marked in polymyalgia rheumatica and the incidence of vascular symptoms, particularly those involving the eye, is higher in temporal arteritis (Hollenhorst, Brown, Wagener and Shick 1960; Meadows 1967).

Cervical and lumbar spondylosis, osteoarthrosis and periarthritis of the shoulders are not accompanied by a significant elevation of the sedimentation rate. The various connective tissue diseases can usually be distinguished by one or more of the laboratory investigations, although the chief symptoms of pain and stiffness particularly in the morning suggest this group of diseases. Rheumatoid arthritis may be particularly difficult to differentiate as the disease commonly starts in the shoulder in older patients (Ehrlich, Katz and Cohen 1970), and in patients over sixty years the serological tests for rheumatoid factor are often negative. Multiple myelomatosis and other neoplastic diseases can mimic the symptoms of polymyalgia rheumatica and the general ill-health and loss of weight will require appropriate investigations in some cases. Psychological causes for the symptoms are often suggested and delay diagnosis. No case of connective tissue disease, rheumatoid arthritis or neoplastic disease has been found in our series so far, but the follow-up period is short.

\section{TREATMENT}

Most of the symptoms of polymyalgia rheumatica are helped by salicylates, phenylbutazone, indomethacin or other analgesic and anti-inflammatory agents (Gordon 1960, Bagratuni 1963). Some patients in our series were so much better with these drugs at the time of referral that no other treatment was given. However, these drugs probably do not control any underlying arteritis, and may allow visual disturbances and other vascular signs to develop while the myalgic symptoms are controlled (Wadman and Werner 1967; Easterbrook, Baxter and Martin 1967).

Corticosteroids dramatically relieve the myalgic symptoms and also suppress the arteritis. It is now usual to use these drugs in patients in whom the disease is severe or in whom there are symptoms and signs or pathological evidence of arteritis. However, because there is often great difficulty in establishing the presence of vasculitis it seems sensible to us and others (Simkin and Healey 1969) to prescribe corticosteroids in almost every case. Hesitancy on the part of some authors to adopt this approach to treatment is based upon the finding 
that visual complications usually develop within twelve weeks of the onset of the myalgia (Fessel and Pearson 1967), although an interval of thirty-five months has been recorded (Bruk 1967), and because large doses of corticosteroids carry increased risks in an older population. Indeed in our series the development of heart failure in one patient (Case 20) and the death of a second patient (Case 21) from the perforation of a known gastric ulcer could perhaps be attributed to the corticosteroids, although the dosage of prednisolone was only 10 milligrams daily in both cases. However, the possibility of uncontrolled arteritis as the cause of these incidents was not excluded. Many authors recommend more than 20 milligrams of prednisolone daily with a gradual reduction over many months. However, in our experience it is rarely necessary to exceed 20 milligrams of prednisolone daily, and with frequent follow-up visits the dosage can be reduced to less than 10 milligrams daily within two months.

Corticosteroids probably shorten the course of the disease: the drugs can usually be withdrawn within eighteen months (Andrews 1966); whereas those patients who are untreated or only receive non-steroidal drugs run a course of two to four years (Gordon 1960; Davison, Spiera and Plotz 1966). The patients' symptoms are the best guide to management of the disease, as the sedimentation rate and other laboratory abnormalities tend to be slower in returning to normal. All our patients are symptom-free and only two patients have required corticosteroid drugs for longer than eighteen months. In five patients corticosteroids were not used and the disease settled after a mean interval of twelve months. Based on the foregoing facts this probably reflects milder disease and a lengthy period before referral rather than any special benefit of non-steroidal, anti-inflammatory drugs.

\section{SUMMARY}

1. Polymyalgia rheumatica is a disease of unknown cause, manifested by severe pain and stiffness of the muscles of the shoulder and pelvic girdles, which may be accompanied by a variety of other systemic symptoms.

2. Twenty-three patients with this condition are reviewed.

3. The difficulties of diagnosis, especially when presenting as an orthopaedic problem, are discussed.

\section{REFERENCES}

Alestig, K., and Barr, J. (1963): Giant-Cell Arteritis: A Biopsy Study of Polymyalgia Rheumatica, Including One Case of Takayasu's Disease. Lancet, 1, 1228.

Andrews, F. M. (1966): Polymyalgia Rheumatica. In Modern Trends in Rheumatology, 1, p. 362. Edited by A. G. S. Hill. London: Butterworths.

Bagratuni, L. (1963): Prognosis in the Anarthritic Rheumatoid Syndrome. British Medical Journal, 1, 513.

Ball, J., and Lawrence, J. S. (1961): Epidemiology of the Sheep Cell Agglutination Test. Annals of the Rheumatic Diseases, 20, 235.

Bevan, A. T., Dunnill, M. S., and Harrison, M. J. G. (1968): Clinical and Biopsy Findings in Temporal Arteritis. Annals of the Rheumatic Diseases, 27, 271.

BruCE, W. (1888): Senile Rheumatic Gout. British Medical Journal, 2, 811.

Bruk, M. I. (1967): Articular and Vascular Manifestations of Polymyalgia Rheumatica. Annals of the Rheumatic Diseases, 26, 103.

Chalmers, T. M., Alexander, W. R. M., and Duthie, J. J. R. (1964): Polymyalgia; Problems of Differential Diagnosis. Annals of the Rheumatic Diseases, 23, 123.

Cullen, J. F. (1967): Occult Temporal Arteritis. British Journal of Ophthalmology, 51, 513.

Davison, S., Spiera, H., and Plotz, C. M. (1966): Polymyalgia Rheumatica. Arthritis and Rheumatism, 9, 18.

Desser, E. J. (1969): Miosis, Trismus, and Dysphagia. An Unusual Presentation of Temporal Arteritis. Annals of Internal Medicine, 71, 961.

Dixon, A. St J., Beardwell, C., Kay, A., Wanka, J., and Wong, Y. T. (1966): Polymyalgia Rheumatica and Temporal Arteritis. Annals of the Rheumatic Diseases, 25, 203.

Easterbrook, W. M., Baxter, D. W., and Martin, J. R. (1967): Temporal Arteritis Developing During Indomethacin Therapy of Polymyalgia Rheumatica. Canadian Medical Association Journal, 97, 296.

Ehrlich, G. E., Katz, W. A., and Cohen, S. H. (1970): Rheumatoid Arthritis in the Aged. Geriatrics, 25, 103.

VOL. 53 B, NO. 4, NOVEMBER 1971 
Fessel, W. J., and Pearson, C. M. (1967): Polymyalgia Rheumatica and Blindness. New England Journal of Medicine, 276, 1403.

Gillanders, L. A., Strachan, R. W., and Blair, D. W. (1969): Temporal Arteriography. A New Technique for the Investigation of Giant Cell Arteritis and Polymyalgia Rheumatica. Annals of the Rheumatic Diseases, 28, 267.

Goodman, M. A., and Pearson, C. M. (1969): Polymyalgia Rheumatica and Associated Arteritis: A Review. California Medicine, 111, 453.

Gordon, I. (1960): Polymyalgia Rheumatica. Quarterly Journal of Medicine, 29, 473.

Grahame, R., Bluestone, R., and Holt, P. J. L. (1968): Recurrent Blanching of the Tongue Due to Giant Cell Arteritis. Annals of Internal Medicine, 69, 781.

Gunderson, C. H. (1970): Polymyalgia Rheumatica in Patients of Military Age. Military Medicine, 135, 28.

Hamrin, B., Jonsson, N., and Hellsten, S. (1968): "Polymyalgia Arteritica": Further Clinical and Histopathological Studies with a Report of Six Autopsy Cases. Annals of the Rheumatic Diseases, $27,397$.

Hamrin, B., Jonsson, N., and Landberg, T. (1965): Involvement of Large Vessels in Polymyalgia Arteritica. Lancet, 1, 1193.

HART, C. T. (1967): Formed Visual Hallucinations: A Symptom of Cranial Arteritis. British Medical Journal, $3,643$.

Henderson, A. H. (1967): Tongue Pain with Giant Cell Arteritis. British Medical Journal, 4, 337.

Hollenhorst, R. W., Brown, J. R., Wagener, H. P., and Shick, R. M. (1960): Neurologic Aspects of Temporal Arteritis. Neurology, 10, 490.

Hunder, G. G., Disney, T. F., and Ward, L. E. (1969): Polymyalgia Rheumatica. Mayo Clinic Proceedings, 44, 849.

Hunder, G. G., and ShePs, S. G. (1967): Intermittent Claudication and Polymyalgia Rheumatica: Association with Panarteritis. Archives of Internal Medicine, 119, 638.

Kogstad, O. A. (1965): Polymyalgia Rheumatica and its Relation to Arteritis Temporalis. Acta Medica Scandinavica, 178, 591.

Lockshin, M. D. (1970): Diplopia as Early Sign of Temporal Arteritis. Report of Two Cases. Arthritis and Rheumatism, 13, 419.

Meadows, S. P. (1967): Giant-cell Arteritis and Blindness. Hospital Medicine, 1, 835.

Nuessle, W. F., Miller, H. E., and Norman, F. C. (1967): Polymyalgia Rheumatica. Report of 7 Cases. Minnesota Medicine, 50, 1483.

Paulley, J. W., and Hughes, J. P. (1960): Giant-cell Arteritis, or Arteritis of the Aged. British Medical Journal, $2,1562$.

Plotz, C. M., and Spiera, H. (1969): Polymyalgia. Bulletin on the Rheumatic Diseases, 20, 578.

Polasky, N., Polasky, S. H., Magenheim, H., and Abrams, N. R. (1965): Giant-Cell Arteritis. Journal of the American Medical Association, 191, 341.

Simkin, P. A., and Healey, L. A. (1969): Giant Cell Arteritis with Polymyalgia Rheumatica, Loss of Vision, and Abdominal Symptoms Occurring During a Four Year Course. Arthritis and Rheumatism, 12, 147.

Wadman, B., and Werner, I. (1967): Therapeutic Hazards of Phenylbutazone and Oxyphenbutazone in Polymyalgia Rheumatica. Lancet, 1, 597.

Weissenbach, R., Nobillot, A., Freneaux, R., and Coste, F. (1963): Pseudo-polyarthrite Rhizomélique. La Semaine des Hôpitaux de Paris, 39, 2073.

Wilske, K. R., and Healey, L. A. (1967): Polymyalgia Rheumatica: A Manifestation of Systemic Giant-cell Arteritis. Annals of Internal Medicine, 66, 77. 